\title{
Feral pigeons (Columba livia) as potential reservoirs of Salmonella sp. and Escherichia coli
}

\author{
Pombos de vida livre (Columba livia) e seu potencial \\ como reservatórios de Salmonella sp. e Escherichia coli
Ruben Horn Vasconcelos ${ }^{1 *}$, Régis Siqueira de Castro Teixeira', Isaac Neto Goes da Silva', Elisângela de Souza Lopes', William Cardoso Maciel'

\begin{abstract}
This study aimed to review the scientific literature for information about free-living pigeons (Columba livia) as potential reservoirs of Salmonella sp. and Escherichia coli. Rock doves are currently adapted to the urban environment and distributed all over the world. These birds carry microorganisms that are pathogenic for man and other animals, such as bacteria, viruses, fungi and parasites. Among these microorganisms, Salmonella is a pathogenic genus that cause severe economic losses and it is zoonotic, causing foodborne infections in humans. In addition, Escherichia coli is an worrisome species involved in the poultry industry. However, this micro-organism is also a risk to the public health, considering pathotypes that are known to cause diseases in man have been isolated from feral pigeons. The infections caused by these bacteria depend on virulence factors that provide the necessary tools to develop the disease. These factors are encoded by genes that may be found in pathogenicity islands inside the bacterial genome. In addition, pigeons may harbor antimicrobial-resistant bacteria, which may pass this characteristic to other strains, and present a risk to the public health as well. In conclusion, pigeons are reservoirs of strains of Salmonella sp. and Escherichia coli that may present high levels of resistance to antibiotics.
\end{abstract}

KEYWORDS: rock pigeon; zoonosis; virulence; antimicrobial resistance.
RESUMO: O objetivo deste estudo foi revisar na literatura científica informaçóes sobre os pombos de vida livre (Columba livia) e seu potencial como reservatórios de Salmonella sp. e Escherichia coli. Os pombos, atualmente adaptados ao meio urbano, encontram-se distribuídos por todo o mundo e carreiam micro-organismos patogênicos ao homem e a outros animais, podendo ser um dos responsáveis pela disseminaçáo de bactérias, fungos, vírus e parasitas. Entre esses micro-organismos, a Salmonella é um patógeno que gera grande preocupaçáo para a economia e para a saúde pública mundial, uma vez que cria transtornos para a indústria avícola quando ocorrem a contaminação dos plantéis e, consequentemente, o risco para a saúde humana por conta de surtos de toxi-infecçôes alimentares causados por essa bactéria. Outra bactéria preocupante para a indústria avícola e para a saúde pública é a Escherichia coli, uma vez que alguns patotipos patogênicos para o homem já foram isolados de pombos de vida livre. O desenvolvimento de infecçôes por essas bactérias depende de fatores que são codificados por genes de virulência que podem ser encontrados nas ilhas de patogenicidade de cepas patogênicas. Os pombos podem também albergar cepas com carga genética resistente a antibióticos, passíveis de serem transmitidas a outras bactérias e, portanto, de trazer riscos para a saúde pública. Dessa forma, com base nessas informaçóes, conclui-se que os pombos são reservatórios de cepas de Salmonella sp. e Escherichia coli, que podem apresentar elevado potencial de virulência, com altos níveis de resistência antimicrobiana.

PALAVRAS-CHAVE: pombos-da-rocha; zoonose; virulência; resistência antimicrobiana. 
Feral pigeons (Columba livia) are derived from individuals that were captured and domesticated at least five thousand years ago in their natural region, which extends from South Asia to West and South Europe and North Africa. However, these birds are now distributed in the worldwide urban environment (JOHNSTON, 1998). The access to food directly or indirectly from people in the urban environment has stimulated the increase in populations found in major cities around the world. Hence, feral pigeons are now found in close contact with man in public locations, such as squares and parks (HAAG-WACKERNAGEL, 1993; 1995).

These birds may present risk to the public health, considering that at least 60 different micro-organisms that are pathogenic for humans have been isolated from them. Among these pathogens, there are bacteria, such as Salmonella enterica serovar Typhimurium and Chlamydophila psittaci; fungi, such as Cryptococcus neoformans; viruses, like West Nile virus; and a protozoan, Toxoplasma gondii (HAAG-WACKERNAGEL; $\mathrm{MOCH}, 2004)$. All of them have been reported in studies with these birds. In addition, pigeon ectoparasites, such as a tick species, Argas reflexus, may affect humans causing dermatological diseases or systemic allergic reactions (HAAG-WACKERNAGEL, 2005). The direct contact with these birds in captivity may cause an allergic respiratory illness, the pigeon-breeder's disease. This condition is defined as a form of hypersensitivity pneumonitis or extrinsic allergic alveolitis induced by the inhalation of serum proteins that can be found in the excreta and secreta of pigeons, especially on their feathers (ALLEN; SPITERI, 1996).

Feral pigeons are resistant to some diseases, and, since they may not suffer from them or present low mortality rates, they could act as disseminators of pathogens. As an example, experimental infection of Salmonella serovar Enteritidis revealed that these birds may host and disseminate this microorganism (ALBUQUERQUE et al., 2013), which is a risk to the public health. In addition, they may harbor diseases that are important for animal health, such as Newcastle disease (KOMMERS et al., 2001) and ulcerative equine lymphangitis (SZONYI et al., 2014), which could have economic implications. These birds present a considerable capacity of flight, flying distances of up to $5.29 \mathrm{~km}$ in a single day within the urban environment (ROSE et al., 2006). It demonstrates the potential to disperse pathogens throughout long distances, disregarding the control performed by epidemiological barriers.

Therefore, this study aimed to review scientific information regarding feral pigeons (Columba livia) and to evaluate their potential as reservoirs of Salmonella sp. and Escherichia coli.

The Columbiformes order is composed by eight families, 67 genera and 296 living species, in addition to 11 extinct species. Columba livia, commonly known as rock pigeon or domestic pigeon, is inserted in Columbidae family. This species presents body weight ranging from 180 to $355 \mathrm{~g}$, and wide fields, rock cliffs and cities are their known habitat. Although their original geographic distribution was Europe and Asia, currently they are cosmopolitan (VOGEL et al., 1994). The natural diet of the rock pigeons is mainly granivorous, based on seeds and cereals, but also includes small invertebrates. However, free-living pigeons in the urban environment present omnivorous habits, feeding on all sorts of food they have access to (HAAG-WACKERNAGEL; GEIGENFEIND, 2008).

In Brazil, feral pigeons were introduced by Europeans in the $16^{\text {th }}$ century, especially with the arrival of the royal Portuguese family. Since then, these birds have been set free and adapted to the urban environment; similar to what occurred in the rest of the world, where free-living pigeons are now found. Due to the easy access to food and shelter, this species has adapted to the main Brazilian cities, where they can now be found in large populations (BENCKE, 2007; NUNES, 2003).

Populations of pigeons have adjusted to the conditions found in the urban environment so well that it is very hard to eradicate them. However, several techniques have been tested and described. In cities where direct feeding by people in public locations is essential for maintaining the pigeon population, public campaigns aiming to discourage the habit of feeding these birds presented good results to reduce the size of populations (HAAG-WACKERNAGEL, 1995). Other control measures aid in the process of controlling pigeon populations, such as reducing access to possible nest sites, limiting food sources, especially in animal feed factories, and modifying structures, buildings and architectonic designs to be less attractive to this avian species (HAAG-WACKERNAGEL; GEIGENFEIND, 2008; WILLIAMS; CORRIGAN, 1994). An endoscopic technique of vasectomy has been described for pigeons and may be used in future population control (HEIDERICH et al., 2015). Falconry have been reported as an adequate form of controlling synanthropic birds. However, this technique can only reduce a small part of a population (BAXTER; ALLAN, 2006), and its limitations may hinder the application in agricultural productions (ERICKSON et al., 1990). The only location in which pigeons were successfully eradicated was in the archipelago of Galápagos Islands, after a seven-year campaign, involving several methods of capture and elimination. In this site, the use of firearms was the best technique reported. Nevertheless, the support of the community and local agencies was essential for the success of the project. Their role was to speak with the population and explain the importance of eradicating these birds due to the risks they may represent (PHILLIPS et al., 2012).

Feral populations are currently found in the main cities around the world, especially after World War II, when there was an increase in the number of pigeon fanciers, feeders, indirect source of food in cities and, on a lesser scale, offer of seasonally natural food (HAAG-WACKERNAGEL; GEIGENFEIND, 2008). The wide distribution of this species occurs due to the transport of domestic pigeons, which reproduced and were set free in different locations. As a result, these birds may be found even in oceanic islands and locations close to the Arctic Circle, where they could not have reached if it was not by man interference (JOHNSTON; JANIGA, 1995). 
In cities, feral pigeons may be found in all types of human constructions, wherever there are possible nest sites or food available. The natural habitat of the rock pigeon is crevices and cracks in bare cliffs. However, domesticated and freed pigeons have found similarities with their natural sites in human constructions (ALI et al., 2013). In search for nest sites, old buildings are the main choice for these birds, due to the architectonic characteristics and colors that favor the behavior of the animals (SACCHI et al., 2002).

A wide range of feeding behaviors can be observed in feral pigeon populations, which may adjust to human habits when necessary to have access to leftover or spilled food. In addition, they may learn the correct time schedule, in which people in public locations feed them. Possibly, the flexibility these birds present concerning individual foraging strategies, like adapting to different forms of acquiring food, have allowed the survival of the species in the urban environment (ROSE et al., 2006).

Pigeons can be found in sidewalks, facades, paved areas, squares, buildings, public monuments, roofs, entablatures, eaves of buildings, wires and iron girders of bridges. Each individual may excrete up to $12 \mathrm{~kg}$ of droppings per year, which may deteriorate materials, such as calcareous stone and marble. It occurs due to the organic acids, such as uric acid, which may accelerate the process of deterioration of valuable work arts without leaving evidence of the cause (ALI et al., 2013; DEL MONTE; SABBIONI, 1986; HAAG-WACKERNAGEL; GEIGENFEIND, 2008; SACCHI et al., 2002).

These columbids may nest in locations with difficult access, passing through vertical gaps of $5 \mathrm{~cm}$ height and $6 \mathrm{~cm}$ width, and do not tolerate inclinations from 20 to $30^{\circ}$ depending on the material. In order to access confined spaces and acquire food or nesting, they rotate their body to use the lowest circumference of their chest to allow passage through limited gaps. Therefore, data such as these must be considered in the elaboration of architectonic projects to prevent access by these birds (HAAG-WACKERNAGEL; GEIGENFEIND, 2008).

A survey of epidemiological data revealed that pigeons may host 60 species of human pathogens. From these pathogens, 45 are fungi, five are viruses, nine are bacteria and one is a protozoan. However, only five of them are routinely transmitted for humans (HAAG-WACKERNAGEL; MOCH, 2004). In addition, ectoparasites found in these birds may infest humans temporarily, causing skin irritation and itch. Systemic symptoms may also occur, such as fatigue, weakness, dizziness, tachycardia, thoracic oppression and sleepiness (HAAG-WACKERNAGEL; BIRCHER, 2010).

Among the bacteria, members of the genus Salmonella are a risk for human and animal health alike. These pathogens are considered the most commonly transmitted bacteria from poultry products to humans, and they are also associated with severe economic losses (HAFEZ, 2005). The diseases caused by these microorganisms are called salmonellosis, differentiated as: typhoid fever, which affects only humans and superior primates and it is caused by $S$. serovar Typhi; fowl typhoid, caused by $S$. serovar Gallinarum, specific of birds; and pullorum disease, caused by $S$. serovar Gallinarum biovar Pullorum, also specific of birds. Paratyphoid infections are caused by the remaining serotypes and they are zoonotic, affecting animals and humans (BERCHIERI; FREITAS NETO, 2009).

Several studies report the isolation of Salmonella from free-living pigeons in different countries, such as Chile (GONZÁLEZ-ACUÑA, 2007), Brazil (ROCHA-E-SILVA et al., 2014; DE SOUSA et al., 2010), India (DUTTA et al., 2013a), Egypt (OSMAN et al., 2013), Norway (REFSUM et al., 2002), Italy (GARGIULO et al., 2014), Slovenia (DOVČ et al., 2004), and United States of America (PEDERSEN et al., 2006). Despite the constant discussion about the importance of isolating this pathogen from these birds, there is only one report of a transmission from pigeons to humans (LACASSIN et al., 1995). Therefore, the risk of direct transmission of Salmonella to humans may be overestimated.

On the other hand, the transmission of Salmonella from poultry products to humans is well documented (PALMER et al., 2000; DE ALMEIDA et al., 2015; ELGROUD et al., 2015). In addition, the pathogenic potential of a Salmonella strain isolated from a pigeon has been demonstrated in experimentally infected poultry. Hence, these facts generate the hypothesis of a possible involvement of free-living pigeons in the Salmonella cycle in the poultry industry. However, more studies are needed to assess this possibility.

Another microbial species that is frequently isolated from pigeons is Escherichia coli, which colonizes the intestine of individuals soon after hatching, without necessarily causing infection. However, the role of this species as a member of the intestinal microbiota of birds is not fully understood. E. coli may act as a source of vitamins and promote a competition for colonizing sites in the intestinal epithelium against invading pathogenic microorganisms (FERREIRA; KNÖBL, 2009). The pathogenicity of $E$. coli strains that cause colibacillosis is related to virulence factors, which may be used as diagnostic tools to differentiate pathogenic from non-pathogenic strains (JOHNSON, 1991).

Diarrheagenic $E$. coli strains have been isolated from freeliving pigeons in Brazil, which generates a possible zoonotic risk and a role in the transmission of these pathogens (SILVA et al., 2009). Avian Pathogenic E. coli (APEC) is an extra-intestinal pathotype that is composed by strains that are a frequent cause of economic losses on poultry. However, a possible zoonotic risk from these strains has been suggested due to the genetic similarity with Uropathogenic E. coli (UPEC) strains, which cause urinary infections in humans (RODRIGUEZ-SIEK et al., 2005; EWERS et al., 2007; MORA et al., 2012; 2013). Although there are no reports of direct transmission of E. coli from pigeons to humans, the proximity with these birds reinforces the possibility of a zoonotic risk.

In addition to pathogen dissemination, free-living birds may host strains with antimicrobial resistance, which could 
be a risk to humans, considering that resistance to antibiotics is a serious problem from clinical and public health perspectives (GUTIÉRREZ et al., 1990). This issue is one of the main causes of failure in antimicrobial therapy. This mechanism of survival presented by the microorganisms occur naturally or can be acquired. However, acquired resistance is more important due to the fact that it limits viable options of drugs. This form is originated from mutation or gene transference, which may be chromosomic or extra-chromosomic (SPINOSA, 2006).

The dynamics by which different factors involved in antibiotic therapy, such as dose, duration, route of administration and interval of doses, may influence in the selection of resistant strains is not completely understood. However, it is known that bacterial resistance to antibiotics is related to the excessive use of these drugs, especially when used in the wrong way, such as in protocols with short duration or low doses (WHO, 2001). Despite the fact that free-living birds do not have direct access to antibiotics, resistant strains are frequently isolated from these birds (NASCIMENTO et al., 2003; GIBBS et al., 2007; GAUKLER et al., 2009), including pigeons (SILVA et al., 2009; RADIMERSKY et al., 2010; DE SOUSA et al., 2010; DUTTA et al., 2013a; DUTTA et al., 2013b; OSMAN et al., 2013; ROCHA-E-SILVA et al., 2014). In addition, only a few studies involving wild birds far from human contact report resistant strains in their microbiota (NASCIMENTO et al., 2003). On the other hand, most of the studies that report elevated resistance levels in strains from free-living birds are those performed with synanthropic species, which may suggest that the contact with the urban environment is the may source of resistant strains for these birds. Therefore, if free-living birds host resistant strains and the transmission of some of these pathogens have been reported to humans, a hypothetical risk of zoonotic transmission of resistant strains from these birds should be assessed. Hence, the hypothesis of pigeons being reservoirs of resistant strains is suggested as well. However, both theories must yet be tested to assess the risk.

In conclusion, free-living pigeons (Columba livia) host Salmonella sp. and E. coli strains, which may be pathogenic to humans. Nevertheless, despite the fact that the transmission risk is real, it may be overestimated, considering the lack of studies reporting cases caused by this transmission. The role of pigeons in the cycles of Salmonella sp. and E. coli appears to be as reservoirs, which is also important and draws attention to animal productions, especially the poultry industry. In addition, controlling this species is important due to the risk of transmission of other diseases, especially of fungal origin, which are the most common infections transmitted by pigeons.

The frequent reports on isolation of strains resistant to antibiotics from these birds generates the hypothesis of pigeons acting as reservoirs of resistance genes in their microbiotas. This possibility would raise concern due to the zoonotic risk implied. Hence, control of these birds in the urban and animal production environments should be reinforced because of their potential reservoir role. In order to do so, adaptive characteristics of this avian species should be considered to reduce chances of adaptation to the techniques applied.

| | | | | | | | | | | | | | | | | | | | | | | | | | | | | | | | | | | | | | | | | | | | | | | | | | | | | | | | | | | | | | | | | | | | | | | | | | | | | | | | | | | | | | | | | | | | | | | | | | | | | | | | | | | | | | | | | | | | | | | | | | | | | | | | | | | | | | | | | | | | | | | | | | | | | | | | | | | | | | | | | | | | | | | | | | | | | | | | | | | | | | | | | | | | | | | | | | | | | | | | | | | | | | | | | | | | | | | | | | | | | | REFERENCES

ALBUQUERQUE, A.H.; CARDOSO, W.M.; TEIXEIRA, R.S.C.; LOPES, E.S.; SALES, R.J.P.F.; HORN, R.V.; ROCHA-E-SILVA, R.C., BEZERRA, W.G.A.; GOMES-FILHO, V.J.R. Dissemination of Salmonella Enteritidis by experimentally-infected pigeons. Revista Brasileira de Ciência Avícola, v.15, n.3, p. 169-286, 2013.

ALBUQUERQUE, A.H.; TEIXEIRA, R.S.C.; MACHADO, D.N.; LOPES, E.S.; HORN, R.V.; LIMA, B.P.; MARQUES, A.R.; SILVA, I.N.G.; SALLES, R.P.R.; CARDOSO, W.M. Experimental infection of broiler chicks with Salmonella Typhimurium from pigeon (Columba livia). Semina: Ciências Agrárias, Londrina, v.37, n.4, p.1919-1928, 2016. https://doi. org/10.5433/1679-0359.2016v37n4p 1919

ALI, S.; RAKHA, B.A.; HUSSAIN, I.; NADEEM, M.S.; RAFIQUE, M. Ecology of Feral Pigeon (Columba livia) in Urban Areas of Rawalpindi/Islamabad, Pakistan. Pakistan Journal of Zoology, v.45, n.5, p.1229-1234, 2013.

ALLEN, J.T.; SPITERI, M.A. Pigeon breeder's disease. Journal of Laboratory and Clinical Medicine, v.127, n.1, p.10-12, 1996. https://doi.org/10.1002/1099-0496(200008)30:2<145::AIDPPUL 10>3.0.CO;2-4
BAXTER, A.T.; ALLAN, J.R. Use of raptors to reduce scavenging bird numbers at landfill sites. Wildlife Society Bulletin, v.34, n.4, p. $1162-1168,2006$.

BENCKE, B.G.A. POMBOS-DOMÉSTICOS: Sugestões para o controle em Escolas Públicas. Porto Alegre, RS: Fundação zoobotânica do Rio Grande do Sul, 2007. 23p.

BERCHIERI, A.; FREITASNETO, O.C. Salmoneloses aviárias. In:BERCHIERI, A.; SILVA, E.N.; DI FÁBIO, J.; SESTI, L.; ZUANAZE, M.A.F (Ed.). Doenças das aves ed. 2 Campinas: FACTA, seção 4, p.435-454, 2009.

DE ALMEIDA, I.A.Z.C.; PERESI, J.T.M.; ALVES, E.C.; MARQUES, D.F.; TEIXEIRA, I.S.C.; SILVA, S.I.L.; PIGON, S.R.F.; TIBA, M.R.; FERNANDES, S.A. Salmonella Alachua: causative agent of a foodborne disease outbreak. The Brazilian Journal of Infectious Diseases, v. 19, n.3, p.233-238, 2015. https://doi.org/10.1016/j.bjid.2014.12.006

DE SOUSA, E.; BERCHIERI JR, A.; PINTO, A.A.; MACHADO, R.Z.; CARRASCO, A.O.T.; MARCIANO, J.A.; WERTHER, K. Prevalence of Salmonella spp. antibodies to Toxoplasma gondii, and Newcastle disease virus in feral pigeons (Columba livia) in the city of Jaboticabal, Brazil. Journal of Zoo and Wildlife Medicine, v.41, n.4, p.603-607, 2010. https://doi.org/10.1638/2008-0166.1 
DEL MONTE, M.; SABBIONI, C. Chemical and biological weathering of an historical building: Reggio Emilia Cathedral. Science of the total environment, v.50, p.165-182, 1986.

DOVČ, A.; ZORMAN-ROJS, O.; VERGLES RATAJ, A.; BOLEHRIBOVŠEK, V.; KRAPEŽ, U.; DOBEIC, M. Health status of freeliving pigeons (Columba livia domestica) in the city of Ljubljana. Acta Veterinaria Hungarica, v.52, n.2, p.219-226, 2004.

DUTTA, P.; BORAH, M.; SARMAH, R.; GANGIL, R. Isolation of Salmonella Typhimurium from pigeons (Columba livia) in Greater Guwahati, its histopathological impact and antibiogram. Comparative Clinical Pathology, v.22, n.1, p.147-150, 2013 a.

DUTTA, P.; BORAH, M.; SARMAH, R.; GANGIL, R. Isolation, histopathology and antibiogram of Escherichia coli from pigeons (Columba livia). Veterinary World, v.6, n.2, p.91-94, $2013 \mathrm{~b}$.

ELGROUD, R.; GRANIER, S.A.; MARAULT, M.; KEROUANTON, A.; LEZZAR, A.; BOUZITOUNA-BENTCHOUALA, C.; BRISABOIS,A.; MILLEMANN, Y.; Contribution of Avian Salmonella enterica Isolates to Human Salmonellosis Cases in Constantine (Algeria). BioMed Research International, v.2015, 2015.

ERICKSON, W.A.; MARSH, R.E.; SALMON, T.P. A review of falconry as a bird-hazing technique. Proceedings of the Fourteenth Vertebrate Pest Conference, v.25, 1990.

EWERS, C.; LIA, G.; WILKING, H.; KIEBLING, S.; ALT, K.; ANTÁO, E.M; LATURNUS, C.; DIEHL, I.; GLODDE, S.; HOMEIER, T.; BÖHNKE, U.; STEINRÜCK, H.; PHILIPP, H.-C.; WIELER, L.H. Avian pathogenic, uropathogenic, and newborn meningitis-causing Escherichia coli: How closely related are they? International Journal of Medical Microbiology, v.297, p.163-176, 2007.

FERREIRA, A.J.P.; KNÖBL, T. Colibacilose Aviária. In: BERCHIERI, A.; SILVA, E.N.; DI FÁBIO, J.; SESTI, L.; ZUANAZE, M.A.F. (Ed.). Doenças das aves. 2 ed. Campinas: FACTA, seção 4, p.435-454, 2009.

GARGIULO, A.; RUSSO, T.P.; SCHETTINI, R.; MALLARDO, K.; CALABRIA, M.; MENNA, L.F.; RAIA, P.; PAGNINI, U.; CAPUTO, V.; FIORETTI, A.; DIPINETOL. Occurrence of enteropathogenic bacteria in urban pigeons (Columba livia) in Italy. Vector-Borne and Zoonotic Diseases, v.14, n.4, p.251-255, 2014.

GAUKLER, S.M.; LINZ, G.M.; SHERWOOD, J.S.; DYER, N.W.; BLEIER, W.J.; WANNEMUEHLER, Y.M.; NOLAN, L.K.; LOGUE, C.M. Escherichia coli, Salmonella, and Mycobacterium aviumsubsp. Paratuberculosis in Wild European Starlings at a Kansas Cattle Feedlot. Avian Diseases, v.53, n.4, p.544-551, 2009.

GIBBS, P.S.; KASA, R.; NEWBREY, J.L.; PETERMANN, S.R.; WOOLEY, R.E; VINSON, H.M.; REED, W. Identification, Antimicrobial Resistance Profiles, and Virulence of Members from the Family Enterobacteriaceae from the Feces of Yellow-Headed Blackbirds (Xanthocephalus xanthocephalus) in North Dakota. Avian Diseases, v.51, n.3, p.649-655, 2007. https:// doi.org/10.1637/0005-2086(2007)51 [649:IARPAV]2.0.CO;2

GONZÁLEZ-ACUÑA, D.; SILVA, F.; MORENO, L.; CERDA, F.; DONOSO, S.; CABELLO, J.; LÓPEZ, J. Detección de algunos agentes zoonóticos em la paloma doméstica (Columba livia) em la ciudad de Chillán, Chile. Revista chilena de infectología, v.24, n.3, p.199-203, 2007. http://dx.doi.org/10.4067/ S0716-10182007000300004
GUTIÉRREZ, L.M.; GARCIA-LOPEZ, M.L.; OTERO, A.; GARCIAFERNANDEZ, M.C.; MORENO, B. Incidence of staphylococci in ovine mastitic milk and antibiotic susceptibility of the strains. Milchwissenschaft, v.45, p.778-781, 1990.

HAAG-WACKERNAGEL, D. Parasites from feral pigeons as a health hazard for humans. Annals of Applied Biology, v.147, n.2, p.203-210, 2005. https://doi.org/10.1111/j.1744-7348.2005.00029.x

. Regulation of thestreet pigeon in Basel. Wildlife Society Bulletin, v.23, n.2,p.256-260, 1995.

Street pigeons in Basel. Nature, v.361, p.200, 1993.

HAAG-WACKERNAGEL, D.; BIRCHER, A.J. Ectoparasites from feral pigeons affecting humans. Dermatology, v. 220, n. 1, p. 82-92, 2010. https://doi.org/10.1159/000266039

HAAG-WACKERNAGEL, D.; GEIGENFEIND, I. Protecting buildings against feral pigeons. European Journal of Wildlife Research, v.54, n.4, p.715-721, 2008.https://doi.org/10.1007/s10344-008-0201-z

HAAG-WACKERNAGEL, D.; MOCH, H. Health hazards posed by feral pigeons. Journal of Infection, v.48, n.4, p.307-313, 2004.

HAFEZ, H.M. Perspectiva global de enfermidades emergentes e re-emergentes em aves. In: Conferência Apinco 2005 de ciência e tecnologia avícolas, Anais. Santos: FACTA, 2005. p.123-138.

HEIDERICH, E.; SCHILDGER, B.; LIERZ, M. Endoscopic vasectomy of male feral pigeons (Columba livia) as a possible method of population control. Journal of avian medicine and surgery, v. 29 , n. 1, p. 9-17, 2015. https://doi.org/10.1647/2013-063

JOHNSON, J.R. Virulence Factors in Escherichia coli Urinary Tract Infection. Clinical Microbiology Reviews, v.4, n. 1, p.80-128, 1991.

JOHNSTON, R.F. Feral pigeons. The Kansas School Naturalist, v.42, n.2, p.1-15, 1998.

JOHNSTON, R.F.; JANIGA, M. Feral pigeons. Oxford University Press on Demand, 1995. 320p.

KOMMERS, G.D.; KING, D.J.; SEAL, B.S.; BROWN, C.C. Virulence of pigeon-origin Newcastle disease virus isolates for domestic chickens. Avian diseases, v.45, n.4, p.906-921, 2001.

LACASSIN, F.; MINO, J.C.; BENOIT, C.; PERRONNE, C.; LEPORT, C.; VILDÉ, J.L. A propos d'un cas de salmonellose aviaire [A case of avian salmonellosis]. Revista Medicina Interna, v. 16, p.77-78, 1995.

MORA, A.; LÓPEZ, C.; HERRERA, A.; VISO, S.; MAMANI, R.; DHABI, G.; ALONSO, M.P.; BLANCO, M.; BLANCO, J.E.; BLANCO, J. Emerging avian pathogenic Escherichia coli strains belonging to clonal groups 011 :H4-D-ST2085 and 011 1:H4-D-ST 117 with high virulencegene content and zoonotic potential. Veterinary Microbiology, v.156, p.347-352, 2012.https://doi.org/10.1016/j.vetmic.2011.10.033

MORA, A.; VISO, S.; LÓPEZ, C.; ALONSO, M.P.; GARCÍA-GARROTE, F.; DABHI, G.; MAMANI, R.; HERRERA, A.; MARZOA, J.; BLANCO, M.; BLANCO, J.E.; MOULIN-SCHOULEUR, M.; SCHOULEUR, C.; BLANCO, J. Poultry as reservoir for extraintestinal pathogenic Escherichia coli 045:K 1:H7-B2-ST95 in humans. Veterinary Microbiolology, 2013. https://doi.org/10.1016/j.vetmic.2013.08.007 
NASCIMENTO, A.M.; CURSINO, L.; GONÇALVES-DORNELAS, H.; REIS, A.; CHARTONE-SOUZA, E.; MARINI, M.Â. Antibiotic-resistant Gram-negative bacteria in birds from the Brazilian Atlantic forest. The Condor, v.105, n.2, p.358-361, 2003. https://doi. org/10.1650/0010-5422(2003)105[0358:AGBIBF]2.0.CO;2

NUNES, V.F.P. Pombos urbanos: o desafio de controle. Biológico, São Paulo, v.65, n.1/2, p.89-92, 2003.

OSMAN, K.M.; MEHREZ, M.; ERFAN, A.M.; NAYERAH, A. Salmonella enterica isolated from pigeon (Columba livia) in Egypt. Foodborne pathogens and disease, v. 10, n.5, p.481-483, 2013.

PALMER, S.; PARRY, S.; PERRY, D.; SMITH, R.; EVANS, M.; NEHAUL, L.; ROBERTS, R.; WALAPU, M.; WRIGHTD. The role of outbreaks in developing food safety policy: population based surveillance of salmonella outbreaks in Wales 1986-98. Epidemiology and infection, v.125, n.3, p.467-472, 2000.

PEDERSEN, K.; CLARK, L.; ANDELT, W.F.; SALMAN, M.D. Prevalence of Shiga toxin-producing Escherichia coli and Salmonella enterica in rock pigeons captured in Fort Collins, Colorado. Journal of Wildlife Diseases, v.42, n. 1, p.46-55, 2006.

PHILLIPS, R.B.; COOKE, B.D.; CARRIÓN, V.; SNELL, H.L. Eradication of rock pigeons, Columba livia, from the Galápagos Islands. Biological Conservation, v.147, n.1, p.264-269, 2012.

RADIMERSKY, T.; FROLKOVA, P.; JANOSZOWSKA, D.; DOLEJSKA, M.; SVEC, P.; ROUBALOVA, E.; CIKOVA, P.; CIZEK, A.; LITERAK, I. Antibiotic resistance in faecal bacteria (Escherichia coli, Enterococcus spp.) in feral pigeons. Journal of Applied Microbiology, v.109, n.5, p.1687-1695, 2010.

REFSUM, T.; HANDELAND, K.; BAGGESEN, D.L.; HOLSTAD, G.; KAPPERUD, G. Salmonellae in avian wildlife in Norway from 1969 to 2000. Applied and Environmental Microbiology, v.68, n. 11 , p.5595-5599, 2002.

ROCHA-E-SILVA, R.C.; CARDOSO, W.M.; TEIXEIRA, R.S.C.; ALBUQUERQUE, A.H.; HORN, R.V.; LOPES, E.S.; GOMES FILHO, V.J.R.; ALMEIDA, C.P.; SANTOS, I.C.L.; MACHADO, D.N.; LIMA, S.V.G.; CARNEIRO, I. S. Isolation of Salmonella enterica subsp. enterica (0: 4, 5: i) and Salmonella enterica subsp. Typhimurium from free-living domestic pigeons (Columba livia). Arquivo Brasileiro de Medicina Veterinária e Zootecnia, v.66, n.5, p.1435-1438, 2014.
RODRIGUEZ-SIEK, K.E.; GIDDINGS, C.W.; DOETKOTT, C.; JOHNSON, T.J.; FAKHR, M.K.; NOLAN, L.K. Comparison of Escherichia coli isolates implicated in human urinary tract infection and avian colibacillosis. Microbiology, v.151, p.2097$2110,2005$.

ROSE, E.; NAGEL, P.; HAAG-WACKERNAGEL, D. Spatiotemporal use of the urban habitat by feral pigeons (Columba livia). Behavioral Ecology and Sociobiology, v.60, n.2, p.242254, 2006.

SACCHI, R.; GENTILLI, A.; RAZZETTI, E.; BARBIERI, F. Effects of building features on density and flock distribution of feral pigeons Columba livia var. domestica in an urban environment. Canadian Journal of Zoology, v.80, n.1, p.48-54, 2002.

SILVA, V.L.; NICOLI, J.R.; NASCIMENTO, T.C.; DINIZ, C.G. Diarrheagenic Escherichia coli strains recovered from urban pigeons (Columba livia) in Brazil and their antimicrobial susceptibility patterns. Current Microbiology, v.59, n.3, p.302308, 2009.

SPINOSA, H.S. Considerações Gerais sobre os Antimicrobianos. In: SPINOSA, H.S.; GÓRNIAK, S.L.; BERNARDI, M.M. Farmacologia Veterinária, ed. 4, 2006.

SZONYI, B.; SWINFORD, A.; CLAVIJO, A.; IVANEK, R. Re-emergence of pigeon fever (Corynebacterium pseudotuberculosis) infection in Texas horses: epidemiologic investigation of laboratorydiagnosed cases. Journal of Equine Veterinary Science, v.34, n.2, p.281-287, 2014.

VOGEL, C.; GERLACH, H.; LÖFFLER, M. Columbiformes. In: RICHIE, B.W.; HARRISON, G.J.; HARRISON, L.R. Avian Medicine: Principles and Application. Wingers Publishing, 1994. cap.44, p. $1200-1217$

WHO - World Health Organization. WHO consultation on the monitoring of antimicrobial usage in food animals for the protection of human health. WHO/CDS/CSR/DRS/2001.21, Oslo, Norway, 2001.

WILLIAMS, D.E.; CORRIGAN, R.M. Pigeons (rock doves). The Handbook: Prevention and Control of Wildlife Damage, p.69, 1994. 